\title{
Effects of GH replacement therapy in adults on serum levels of leptin and ghrelin: the role of lipolysis
}

\author{
E T Vestergaard, T K Hansen, S Nielsen, N Moller, J S Christiansen and J O L Jorgensen \\ Medical Department M (Endocrinology and Diabetes), Aarhus University Hospital, Dk-8000 Aarhus C, Denmark
}

(Correspondence should be addressed to E T Vestergaard; Email: etv@dadlnet.dk)

\begin{abstract}
Objective: The regulation and function of systemic ghrelin levels appear to be associated with food intake and energy balance rather than GH. Since GH, in turn, acutely induces lipolysis and insulin resistance in skeletal muscle, we aimed to study the isolated and combined effects of $\mathrm{GH}$, free fatty acids (FFAs) and insulin sensitivity on circulating ghrelin levels in human subjects.

Design: Seven GH-deficient patients (aged $37 \pm 4$ years (mean \pm S.E.)) were studied on four occasions in a $2 \times 2$ factorial design with and without GH substitution and with and without administration of acipimox, which lowers FFA levels by inhibition of the hormone-sensitive lipase, in the basal state and during a hyperinsulinemic euglycemic clamp.

Results: Serum FFA levels decreased with acipimox administration irrespective of GH status. The GHinduced reduction in insulin sensitivity was countered by acipimox. Fasting ghrelin levels decreased insignificantly during $\mathrm{GH}$ administration alone, but were reduced by 33\% during co-administration of GH and acipimox (Aci) (in ng/l): 860 120 ( $-\mathrm{GH}-\mathrm{Aci}), 711 \pm 130(-\mathrm{GH}+$ Aci), $806 \pm 130$ $(+\mathrm{GH}-\mathrm{Aci}), 574 \pm 129(+\mathrm{GH}+\mathrm{Aci}), P<0.01$. The clamp was associated with a further, moderate lowering of ghrelin. GH and acipimox induced a reciprocal $25 \%$ increase in serum leptin levels $(\mu \mathrm{g} / \mathrm{l})$ : 11.2 $\pm 4.4(-\mathrm{GH}-\mathrm{Aci}), 11.7 \pm 4.4(-\mathrm{GH}+\mathrm{Aci}), 11.5 \pm 4.4(+\mathrm{GH}-\mathrm{Aci}), 13.9 \pm 4.2(+\mathrm{GH}+\mathrm{Aci})$, $P=0.005$.

Conclusion: Our data suggest that antilipolysis via suppression of the hormone-sensitive lipase in combination with GH administration is associated with significant and reciprocal changes in ghrelin and leptin.
\end{abstract}

European Journal of Endocrinology 153 545-549

\section{Introduction}

The regulation and function of circulating ghrelin is complex and not fully understood. Since ghrelin, which is produced by the stomach, is the endogenous ligand of the growth hormone secretagog (GHS) receptor, it was anticipated that the circulating levels of this peptide would be linked to the endogenous growth hormone (GH) secretion. However, the increased GH secretion observed during conditions such as exercise (1), fasting (2), and hypoglycemia (3), does not appear to be subserved by ghrelin. If anything, data obtained in acromegaly $(4,5)$ and following $\mathrm{GH}$ administration $(6,7)$ indicate that $\mathrm{GH}$ to a moderate extent suppresses systemic ghrelin levels. By contrast, the circadian pattern of ghrelin is closely associated with food intake with high preprandial levels, a postprandial suppression, and intermediary and more stable nocturnal concentrations (8). It has been suggested that ghrelin acts as a meal initiator, which fits with experimental data in humans and in rodent models showing that ghrelin is orexigenic $(9,10)$. In addition, ghrelin levels are low in obesity and increase following weight loss $(11,12)$. Administration of insulin suppresses ghrelin levels irrespective of glycemia (13), and ghrelin is inversely correlated with endogenous insulin levels (8). Interestingly, insulin resistance per se also appears to be a negative determinant of ghrelin (14-17). GH induces lipolysis, insulin resistance and hyperinsulinemia (18), which may influence its impact on ghrelin secretion. In the present study, we have been able to factor out the effects of $\mathrm{GH}$, insulin and insulin sensitivity on serum concentrations of endogenous ghrelin. Using a $2 \times 2$ factorial design we evaluated the impact of GH and acipimox, a potent inhibitor of lipolysis which antagonizes the insulin antagonistic effects of $\mathrm{GH}$, on circulating ghrelin concentrations in the basal state and during a hyperinsulinemic euglycemic glucose clamp. 


\section{Subjects and methods}

Seven adult GH-deficient patients (six men and one woman) were included in the study. Patient characteristics are summarized in Table 1. The diagnosis of GH deficiency was ultimately based on a GH response $<3 \mu \mathrm{g} / \mathrm{l}$ after an arginine stimulation test and/or an insulin tolerance test. All pituitary replacement therapy, including GH treatment, was administered in an unchanged dosage for at least 6 months before the study.

Informed consent was obtained from all participants, and the local ethics committee approved the study.

All seven patients were studied four times in random order: after discontinuation of GH replacement for 2 days (- $\mathrm{GH}-\mathrm{Aci})$, after discontinuation of $\mathrm{GH}$, but with administration of acipimox (Aci) $(-\mathrm{GH}+\mathrm{Aci})$, during continuation of $\mathrm{GH}$ replacement $(+\mathrm{GH}-\mathrm{Aci})$, and during continuation of GH replacement plus administration of acipimox $(+\mathrm{GH}+\mathrm{Aci})$. $\mathrm{GH}$ was administered as subcutaneous self-injections at $2200 \mathrm{~h}$; for study conditions - GH - Aci and - GH + Aci, the last two GH injections were discontinued. In study conditions $-\mathrm{GH}+\mathrm{Aci}$ and $+\mathrm{GH}+$ Aci, the patients received four doses of acipimox $250 \mathrm{mg}$, p.o., with two doses administered at 2000 and $2300 \mathrm{~h}$ the evening before and two doses administered at 0600 and $1000 \mathrm{~h}$ on the day of the metabolic study. The metabolic studies were performed between 0800 and $1400 \mathrm{~h}(0-360 \mathrm{~min})$. Intravenous catheters were placed in an antecubital vein. The subjects were studied in the basal post absorptive state for $180 \mathrm{~min}(0800-1100 \mathrm{~h})$. At $1100-1400 \mathrm{~h}$ a hyperinsulinemic, euglycemic clamp (insulin $0.6 \mathrm{mU} /$ $\mathrm{kg} / \mathrm{min}$; Actrapid, Novo Nordisk, Gentofte, Denmark) was performed. During the insulin infusion plasma glucose was clamped at $5.0 \mathrm{mmol} / \mathrm{l}$ by adjusting the rate of infusion of $20 \%$ glucose according to plasma glucose measurements every $10 \mathrm{~min}$. Insulin sensitivity was estimated by the level of glucose infusion rate (GIR) during the hyperinsulinemic, euglycemic clamp.

Serum ghrelin was measured in one run by a commercial radioimmunometric assay (Phoenix Pharmaceuticals, Inc., Belmont, CA, USA) using ${ }^{125}$ I-labeled bioactive ghrelin as a tracer and a rabbit polyclonal antibody vs octanoylated and des-octanoylated h-ghrelin (sensitivity: $8 \sim 20 \mathrm{pg} /$ tube according to the manufacturer's information. The assay recognizes the $\mathrm{COOH}$-terminal of ghrelin and as such determines acylated as well as des-acylated ghrelin.

Serum leptin was measured in one run by a commercial ELISA kit (Linco Research, Inc., St Charles, MO, USA) (sensitivity was $0.5 \mathrm{ng} / \mathrm{ml}$ and the intra- and interassay coefficients of variation ranged from 2.6 to 4.6 and from 2.6 to $6.2 \%$ respectively according to the manufacturer's information).

Ghrelin and leptin and were measured at $\mathrm{t}=0,180$ and $360 \mathrm{~min}$.

Plasma glucose was determined in duplicate immediately after the samples were withdrawn using a Beckman glucose analyzer (Beckman Instruments, Palo Alto, CA, USA). Free fatty acids (FFAs) were measured by a commercial kit (Wako Chemicals GmbH, Neuss, Germany).

GH was assayed by a time-resolved immunofluorometric assay (TR-IFMA) (DELFIA, PerkinElmer Life Sciences and Analytical Sciences-Wallac, Turku, Finland). The intra- and interassay coefficients of variation of the GH assay were $1.7-2.4$ and $1.9-3.0 \%$ respectively; the lower detection limit was $0.01 \mu \mathrm{g} / \mathrm{l}$.

Insulin was measured by commercially available immunoassay (DAKO, Glostrup, Denmark).

All results are expressed as means \pm s.e. Statistical calculations were made by analysis of variance (ANOVA) for repeated measures. All non-normally distributed variables were $\log$ transformed to obtain normality. For time series (i.e. circulating hormones), the area under the curve (AUC) was calculated by the trapezoidal method, and comparisons were made by ANOVA. Where appropriate, post hoc comparisons of the different study days were made by means of a paired $t$-test. Correlations were evaluated by Pearson's test. All calculations were carried out using the computer program SPSS version 11.0 (SPSS, Chicago, IL, USA). $P<0.05$ was considered statistically significant.

\section{Results}

Data on energy expenditure, substrate metabolism, and insulin sensitivity from this study have previously been published in a study focussing on the

Table 1 Characterization of subjects.

\begin{tabular}{lccclrl}
\hline Patient & Sex & Age & BMI $\left(\mathrm{kg} / \mathrm{m}^{2}\right)$ & \multicolumn{1}{c}{ Diagnosis } & IGF-I $(\mu \mathrm{g} / \mathrm{l})$ & Insufficient pituitary axes \\
\hline 1 & $\mathrm{~m}$ & 36 & 26.8 & Juxtasellar glioma & 350 & $\mathrm{GH}, \mathrm{T}$ \\
2 & $\mathrm{f}$ & 37 & 38 & Clinically nonfunctioning pituitary adenoma & 266 & $\mathrm{GH}$ \\
3 & $\mathrm{~m}$ & 33 & 38.5 & Head trauma & 287 & $\mathrm{GH}, \mathrm{Gn}$ \\
4 & $\mathrm{~m}$ & 44 & 31.2 & Craniopharyngeoma & 94 & $\mathrm{GH}, \mathrm{C}, \mathrm{T}, \mathrm{Gn}, \mathrm{V}$ \\
5 & $\mathrm{~m}$ & 31 & 27.8 & Idiopathic, childhood-onset & 250 & $\mathrm{GH}, \mathrm{T}$ \\
6 & $\mathrm{~m}$ & 22 & 28.1 & Craniopharyngeoma & 206 & $\mathrm{GH}, \mathrm{T}, \mathrm{Gn}, \mathrm{V}$ \\
7 & $\mathrm{~m}$ & 58 & 26.6 & Cushing disease & 187 & $\mathrm{GH}, \mathrm{C}, \mathrm{T}$ \\
\hline
\end{tabular}

m, male; f, female; BMI, body mass index; IGF-I levels at baseline during GH substition; GH, growth hormone; T, thyrotropin; C, corticotropin; Gn, gonadotropin; V, vasopressin. 
impact of ambient FFA levels on insulin sensitivity (19). In brief, basal levels of insulin, glucose and $\mathrm{HbA}_{1 \mathrm{c}}$ did not differ significantly between the four studies, although insulin levels tended to be lower during the study with acipimox alone (data not shown). Serum FFA levels during the basal period were decreased with acipimox administration irrespective of $\mathrm{GH}$ status: $\mathrm{AUC}_{\mathrm{FFA}}(\mathrm{mmol} / \mathrm{l} \times \mathrm{min})$ : $82.5 \pm 12.3$ for the $-\mathrm{GH}-\mathrm{Aci}$ group vs $18.0 \pm 3.4$ $(-\mathrm{GH}+\mathrm{Aci}) \quad$ vs $101.2 \pm 10.7 \quad(+\mathrm{GH}-\mathrm{Aci}) \quad$ vs $26.4 \pm 7.8(+\mathrm{GH}+\mathrm{Aci}), \quad P<0.01 . \quad$ As expected, serum FFA levels decreased during the clamp, but the relative differences between the four studies prevailed (data not shown). The GH-induced reduction in insulin sensitivity was reversed by co-administration of acipimox: GIR $(\mathrm{mg} / \mathrm{kg} / \mathrm{min}): 4.0 \pm 0.7$ for the $-\mathrm{GH}-$ Aci group vs $5.0 \pm 0.9(-\mathrm{GH}+\mathrm{Aci})$ vs $2.6 \pm 0.6 \quad(+\mathrm{GH}-\mathrm{Aci})$ vs $4.0 \pm 1.3(+\mathrm{GH}+\mathrm{Aci})$, $P<0.01$. As expected, serum GH levels were significantly increased during $\mathrm{GH}$ administration: $\mathrm{AUC}_{\mathrm{GH}}(\mu \mathrm{g} / \mathrm{l} \times \mathrm{min}): 32.3 \pm 12.0$ for the $-\mathrm{GH}-$ Aci group vs $84.8 \pm 31.7(-\mathrm{GH}+\mathrm{Aci})$ vs $242.1 \pm 31.4$ $(+\mathrm{GH}-\mathrm{Aci})$ vs $237.0 \pm 50.6 \quad(+\mathrm{GH}+\mathrm{Aci})$, $P<0.001$.

Total circulating levels of ghrelin at baseline remained unchanged during $\mathrm{GH}$ administration alone $(+\mathrm{GH}-\mathrm{Aci})$ as compared with no treatment $(-\mathrm{GH}-\mathrm{Aci})$ and acipimox only $(-\mathrm{GH}+\mathrm{Aci})$. In contrast, during concomitant administration of $\mathrm{GH}$ and acipimox $(+\mathrm{GH}+\mathrm{Aci})$, total circulating levels of ghrelin were reduced by $33 \%$ (in ng/l: $860 \pm 120$ (-GH - Aci); $711 \pm 130(-\mathrm{GH}+\mathrm{Aci}) ; 806 \pm 130(+\mathrm{GH}-\mathrm{Aci})$; and $574 \pm 129(+\mathrm{GH}+$ Aci); $P<0.01)$ (Fig. 1). The suppressive effect of $\mathrm{GH}$ plus acipimox on ghrelin prevailed during the clamp period (in ng/l: 794 \pm 200 ( $-\mathrm{GH}-\mathrm{Aci}$ ); $570 \pm 133 \quad(-\mathrm{GH}+\mathrm{Aci}) ; \quad 676 \pm 141 \quad(+\mathrm{GH}-\mathrm{Aci}) ;$ $478 \pm 126 \quad(+\mathrm{GH}+\mathrm{Aci}) ; \quad P<0.02) \quad$ (Fig. 1). The $\mathrm{AUC}_{\text {ghrelin }}$ values were also suppressed by $\mathrm{GH}$ plus acipi$\operatorname{mox}($ in $\mu \mathrm{g} / \mathrm{l} \times \min : \quad 333.5 \pm 61.8 \quad(-\mathrm{GH}-\mathrm{Aci})$; $254.8 \pm 46.6(-\mathrm{GH}+\mathrm{Aci}) ; 272.2 \pm 41.5(+\mathrm{GH}-\mathrm{Aci}) ;$ $219.0 \pm 52.2$ (+GH + Aci); $P<0.02)$, (Fig. 2). As expected, ghrelin levels declined during the clamp in all four studies, although the decline failed to reach statistical significance when GH was given alone $(+\mathrm{GH}-\mathrm{Aci})$ (Table 2).

Analysis for correlation between ghrelin and FFA, $\mathrm{GH}$, insulin and GIR for each condition at the time points 0,180 and $360 \mathrm{~min}$ failed to show significance. Linear regression between changes in serum ghrelin and insulin values before and after the clamp also failed to show significance.

Baseline leptin levels remained unchanged during GH administration alone, but were increased by $24 \%$ during concomitant administration of $\mathrm{GH}$ and acipimox (in $\mu \mathrm{g} / \mathrm{l}: 11.2 \pm 4.4(-\mathrm{GH}-\mathrm{Aci}) ; 11.7 \pm 4.4(-\mathrm{GH}+\mathrm{Aci})$; $11.5 \pm 4.4 \quad(+\mathrm{GH}-\mathrm{Aci}) ; \quad 13.9 \pm 4.2 \quad(+\mathrm{GH}+\mathrm{Aci}) ;$ $P=0.005)$ (Fig. 3). After the clamp period no statistically significant differences in leptin levels remained.

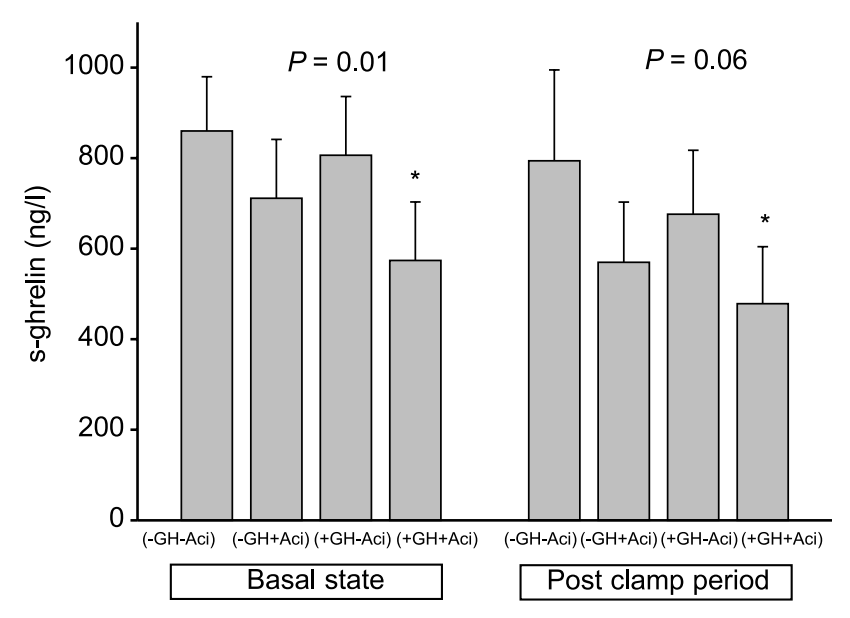

Figure 1 Total circulating serum (s) ghrelin levels (means \pm S.E.) in the basal state and after the clamp period. Ghrelin decreased with concomitant $\mathrm{GH}$ and acipimox treatment $(+\mathrm{GH}+\mathrm{Aci})$ compared with all other conditions. $P$-value refers to overall ANOVA for repeated measurements. Asterisk refers to post hoc paired $t$-test comparing $-\mathrm{GH}-$ Aci with the other conditions; at $\mathrm{t}=0 \mathrm{~min}$, $P=0.02$ and at $\mathrm{t}=360 \mathrm{~min}, P=0.04$.

\section{Discussion}

The aim of this report was to investigate the isolated and combined effects of GH, FFA and insulin sensitivity on circulating ghrelin concentrations in human subjects. To this end, seven GH-deficient adult patients were studied on four occasions in a $2 \times 2$ factorial design with and without GH substitution and with and without administration of acipimox, which lowered FFA levels and increased insulin sensitivity. On each occasion ghrelin was measured in the basal state and during a hyperinsulinemic euglycemic glucose clamp. Our data demonstrate that the combined administration of GH and acipimox significantly suppresses ghrelin levels via apparently independent mechanisms.

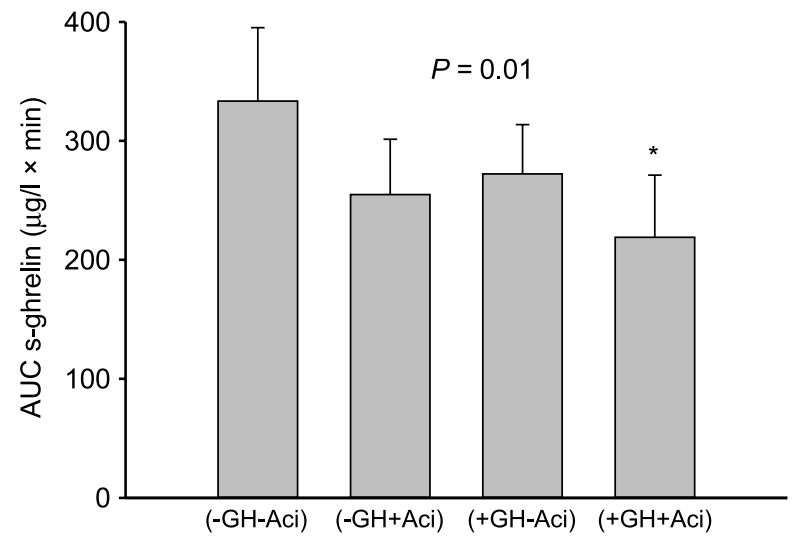

Figure 2 Area under the concentration curve (AUC; means \pm S.E.) for total circulating serum (s) ghrelin levels from $t=0$ to $360 \mathrm{~min}$. $P$-value refers to overall ANOVA for repeated measurements. Asterisk refers to post hoc paired $t$-test comparing - $\mathrm{GH}-\mathrm{Aci}$ with the other conditions; $P=0.03$. 
Table 2 The values for total circulating serum ghrelin at the time points 180 and $360 \mathrm{~min}$ for the four different treatment conditions.

\begin{tabular}{lcc}
\hline & \multicolumn{2}{c}{ S-ghrelin (ng/ml) } \\
\cline { 2 - 3 } Treatment group & $180 \mathrm{~min}$ & $360 \mathrm{~min}$ \\
\hline$-\mathrm{GH}-\mathrm{Aci}$ & $1025 \pm 186$ & $794 \pm 200^{\star}$ \\
$-\mathrm{GH}+\mathrm{Aci}$ & $775 \pm 133$ & $570 \pm 133^{\star}$ \\
$+\mathrm{GH}-\mathrm{Aci}$ & $771 \pm 101$ & $676 \pm 141$ \\
$+\mathrm{GH}+\mathrm{Aci}$ & $690 \pm 166$ & $478 \pm 126^{\star}$ \\
\hline
\end{tabular}

${ }^{*} P<0.05$, comparisons between time points 180 and $360 \mathrm{~min}$.

Each study was performed during identical conditions as regards clock time and substrate background, which is important since ghrelin displays a distinct circadian variation in the fed (8) as well as in the fasting (2) state. Only the study with GH plus acipimox showed a significant change in ghrelin levels (Fig. 1). Since both GH and acipimox influenced FFA levels as well as insulin sensitivity it is difficult to factor out the precise ghrelin lowering mechanism of acipimox. But our data demonstrate that ghrelin levels are not significantly determined by isolated changes in either FFA levels or insulin sensitivity.

Intravenous infusion of lipids does not significantly impact on ghrelin levels (20), but a positive correlation between endogenous FFA levels and ghrelin has been reported (21).

As previously mentioned, the association between $\mathrm{GH}$ status and systemic ghrelin levels remains ambiguous, but the data so far seem to indicate a moderate suppressive effect of high GH levels on ghrelin $(1,4-7)$, whereas the increase in $\mathrm{GH}$ secretion during conditions such as exercise and hypoglycemia is not subserved by ghrelin.

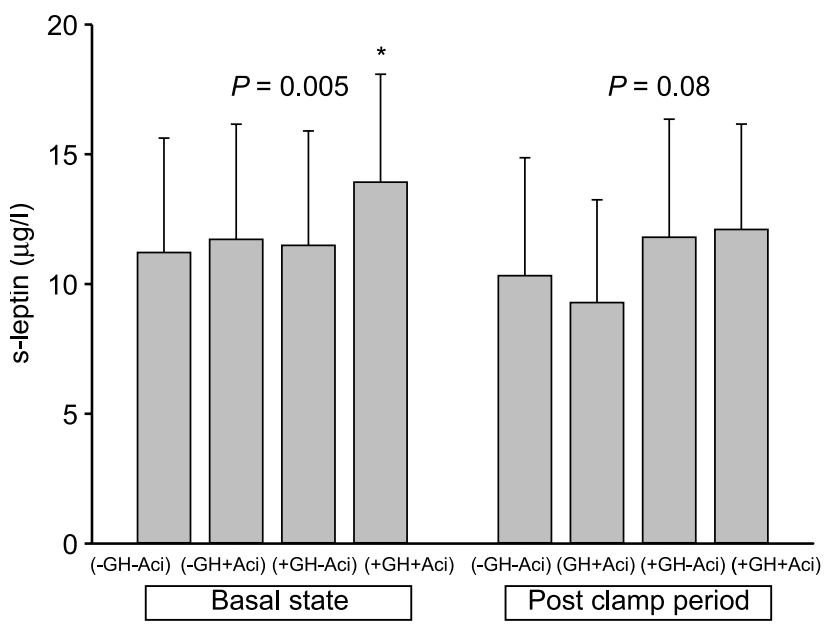

Figure 3 Serum leptin levels (s-leptin; means \pm S.E.) in the basal state and after the clamp period. Leptin increased in the group with concomitant $\mathrm{GH}$ and acipimox treatment $(+\mathrm{GH}+\mathrm{Aci}) \mathrm{com}-$ pared with other conditions in the basal state but not after the clamp period. $P$-values refer to overall ANOVA for repeated measurements. Asterisk refers to post hoc paired $t$-test comparing $-\mathrm{GH}-$ Aci to the other conditions; at $\mathrm{t}=0 \mathrm{~min}, P=0.01$.
In most but not all (22) cross-sectional studies, reduced ghrelin levels are found in subjects with impaired insulin sensitivity (14-17), but insulin resistance has also been associated with a blunted postprandial suppression of ghrelin $(3,21)$. The specific role of insulin appears more evident since most studies including the present show that insulin administration lowers ghrelin levels irrespective of ambient glycemia. Because insulin levels during the basal period were not significantly different on the four study days, we could factor out insulin as a regulator of basal ghrelin levels in this trial. The causal relationship between ghrelin and insulin sensitivity is unclear and our data emphasize that short-term changes in insulin sensitivity per se do not significantly influence serum ghrelin levels. If insulin sensitivity is independently determining ghrelin levels we would, in the present study, expect + GH - Aci to significantly alter ghrelin levels, because insulin sensitivity was significantly decreased in that condition.

We therefore favor the hypothesis that antilipolysis per se as well as GH suppress ghrelin secretion. This observation fits with a recent study in rodents, where inactivation of fatty acid synthase decreased total circulating ghrelin levels and subsequently reduced both food intake and body weight (23). The most significant acute regulator of circulating (i.e. gut derived) ghrelin secretion seems to be food intake, where an increase is observed before each meal followed by a postprandial suppression (12). This has led to the hypothesis that ghrelin is a meal initiating signal, which is compatible with the orexigenic effects of ghrelin derived from experimental data in human as well as rodent models. In line with this view it makes teleological sense that suppression of lipolysis via inhibition of the hormone-sensitive lipase in adipose tissue would suppress ghrelin secretion, since mobilization of FFA is increased with fasting and blocked by food intake. The molecular mechanisms subserving the regulation of ghrelin secretion by the hormone-sensitive lipase (HSL) remains to be elucidated, but the available data suggest that it is not merely mediated by changes in circulating FFA levels. Our study also supports the notion that high GH levels may feedback-inhibit ghrelin secretion, but the effect appears to be moderate and of uncertain physiological significance.

We were surprised to observe that combined administration of $\mathrm{GH}$ and acipimox caused $\mathrm{a} \approx 25 \%$ increase in serum leptin levels, which was reciprocal to the changes in ghrelin. In rodents, leptin stimulates lipolysis and fat oxidation, which is assumed to be mediated by the HSL (24). It could thus be speculated that blockade of HSL-mediated lipolysis could lead to a feedback stimulation of leptin secretion. Long-term GH exposure in humans lowers leptin levels in parallel with a reduction in fat mass, whereas the short-term effects of GH on leptin are uncertain. Thus the reason why increased leptin levels were observed only when 
acipimox and GH were co-administered is not readily explained.

In conclusion, our studies indicate that antilipolysis via suppression of the hormone-sensitive lipase in combination with $\mathrm{GH}$ administration is associated with significant and reciprocal changes in ghrelin and leptin. This novel observation adds to the evidence that the secretion and action of ghrelin predominantly depend on alterations in nutritional background.

\section{References}

1 Dall R, Kanaley J, Hansen TK, Moller N, Christiansen JS, Hosoda H, Kangawa K \& Jorgensen JO. Plasma ghrelin levels during exercise in healthy subjects and in growth hormonedeficient patients. European Journal of Endocrinology 2002147 65-70.

2 Espelund U, Hansen TK, Hojlund K, Beck-Nielsen H, Clausen JT, Hansen BS, Orskov H, Jorgensen JO \& Frystyk J. Fasting unmasks a strong inverse association between ghrelin and cortisol in serum: studies in obese and normal-weight subjects. Journal of Clinical Endocrinology and Metabolism 200590 741-746.

3 Lucidi P, Murdolo G, Di Loreto C, De Cicco A, Parlanti N, Fanelli C, Santeusanio F, Bolli GB \& De Feo P. Ghrelin is not necessary for adequate hormonal counterregulation of insulin-induced hypoglycemia. Diabetes $2002512911-2914$.

4 Cappiello V, Ronchi C, Morpurgo PS, Epaminonda P, Arosio M, Beck-Peccoz P \& Spada A. Circulating ghrelin levels in basal conditions and during glucose tolerance test in acromegalic patients. European Journal of Endocrinology 2002147 189-194.

5 Freda PU, Reyes CM, Conwell IM, Sundeen RE \& Wardlaw SL. Serum ghrelin levels in acromegaly: effects of surgical and longacting octreotide therapy. Journal of Clinical Endocrinology and Metabolism 200388 2037-2044.

6 Eden EB, Burman P, Holdstock C \& Karlsson FA. Effects of growth hormone (GH) on ghrelin, leptin, and adiponectin in GH-deficient patients. Journal of Clinical Endocrinology and Metabolism $2003 \mathbf{8 8}$ 5193-5198.

7 Giavoli C, Cappiello V, Corbetta S, Ronchi CL, Morpurgo PS, Ferrante E, Beck-Peccoz P \& Spada A. Different effects of shortand long-term recombinant hGH administration on ghrelin and adiponectin levels in GH-deficient adults. Clinical Endocrinology $20046181-87$.

8 Cummings DE, Purnell JQ, Frayo RS, Schmidova K, Wisse BE \& Weigle DS. A preprandial rise in plasma ghrelin levels suggests a role in meal initiation in humans. Diabetes $2001 \mathbf{5 0}$ 1714-1719.

9 Wren AM, Seal LJ, Cohen MA, Brynes AE, Frost GS, Murphy KG, Dhillo WS, Ghatei MA \& Bloom SR. Ghrelin enhances appetite and increases food intake in humans. Journal of Clinical Endocrinology and Metabolism 200186 5992-5995.

10 Tschop M, Smiley DL \& Heiman ML. Ghrelin induces adiposity in rodents. Nature $2000 \mathbf{4 0 7} 908-913$.

11 Hansen TK, Dall R, Hosoda H, Kojima M, Kangawa K, Christiansen JS \& Jorgensen JO. Weight loss increases circulating levels of ghrelin in human obesity. Clinical Endocrinology $2002 \mathbf{5 6}$ 203-206.
12 Cummings DE, Weigle DS, Frayo RS, Breen PA, Ma MK, Dellinger EP \& Purnell JQ. Plasma ghrelin levels after diet-induced weight loss or gastric bypass surgery. New England Journal of Medicine $20023461623-1630$.

13 Flanagan DE, Evans ML, Monsod TP, Rife F, Heptulla RA, Tamborlane WV \& Sherwin RS. The influence of insulin on circulating ghrelin. American Journal of Physiology - Endocrinology and Metabolism 2003284 E313-E316.

14 Katsuki A, Urakawa H, Gabazza EC, Murashima S, Nakatani K, Togashi K, Yano Y, Adachi Y \& Sumida Y. Circulating levels of active ghrelin is associated with abdominal adiposity, hyperinsulinemia and insulin resistance in patients with type 2 diabetes mellitus. European Journal of Endocrinology $2004151573-577$.

15 Poykko SM, Kellokoski E, Horkko S, Kauma H, Kesaniemi YA \& Ukkola O. Low plasma ghrelin is associated with insulin resistance, hypertension, and the prevalence of type 2 diabetes. Diabetes 200352 2546-2553.

16 Purnell JQ, Weigle DS, Breen P \& Cummings DE. Ghrelin levels correlate with insulin levels, insulin resistance, and high-density lipoprotein cholesterol, but not with gender, menopausal status, or cortisol levels in humans. Journal of Clinical Endocrinology and Metabolism $2003 \mathbf{8 8} 5747-5752$.

17 Ostergard T, Hansen TK, Nyholm B, Gravholt CH, Djurhuus CB, Hosoda H, Kangawa K \& Schmitz O. Circulating ghrelin concentrations are reduced in healthy offspring of type 2 diabetic subjects, and are increased in women independent of a family history of type 2 diabetes. Diabetologia 200346 134-136.

18 Norrelund H, Djurhuus C, Jorgensen JO, Nielsen S, Nair KS, Schmitz O, Christiansen JS \& Moller N. Effects of GH on urea, glucose and lipid metabolism, and insulin sensitivity during fasting in GH-deficient patients. American Journal of Physiology - Endocrinology and Metabolism 2003285 E737-E743.

19 Nielsen S, Moller N, Christiansen JS \& Jorgensen JO. Pharmacological antilipolysis restores insulin sensitivity during growth hormone exposure. Diabetes 200150 2301-2308.

20 Mohlig M, Spranger J, Otto B, Ristow M, Tschop M \& Pfeiffer AF. Euglycemic hyperinsulinemia, but not lipid infusion, decreases circulating ghrelin levels in humans. Journal of Endocrinological Investigation 200225 RC36-RC38.

21 Anderwald C, Brabant G, Bernroider E, Horn R, Brehm A, Waldhausl W \& Roden M. Insulin-dependent modulation of plasma ghrelin and leptin concentrations is less pronounced in type 2 diabetic patients. Diabetes 200352 1792-1798.

22 Shiiya T, Nakazato M, Mizuta M, Date Y, Mondal MS, Tanaka M, Nozoe S, Hosoda H, Kangawa K \& Matsukura S. Plasma ghrelin levels in lean and obese humans and the effect of glucose on ghrelin secretion. Journal of Clinical Endocrinology and Metabolism 2002 $87240-244$.

$23 \mathrm{Hu}$ Z, Cha SH, van Haasteren G, Wang J \& Lane MD. Effect of centrally administered $\mathrm{C} 75$, a fatty acid synthase inhibitor, on ghrelin secretion and its downstream effects. PNAS $2005 \mathbf{1 0 2}$ 3972-3977.

24 Steinberg GR, Bonen A \& Dyck DJ. Fatty acid oxidation and triacylglycerol hydrolysis are enhanced after chronic leptin treatment in rats. American Journal of Physiology - Endocrinology and Metabolism 2002282 E593-E600.

Received 5 April 2005

Accepted 5 July 2005 